\title{
EFEK LATIHAN INTENSITAS RENDAH DAN SEDANG TERHADAP LEMAK PADA OVERWEIGHT
}

\author{
Rizky Sota Dyaksa*1, Paulus Liben ${ }^{2}$, Edy Mintarto ${ }^{3}$ \\ ${ }^{1,2}$ Jurusan Ilmu Kesehatan Olahraga, FK UNAIR, Surabaya \\ ${ }^{3}$ Jurusan Pendidikan Kepelatihan Olahraga, FIO UNESA, Surabaya \\ e-mail: *1sotadvaksa@vahoo.com
}

\begin{abstract}
Abstrak
Penelitian ini bertujuan untuk mengetahui pengaruh Low Intensity Continuous Training (LICT) dan Moderate Intensity Continuous Training (MICT) terhadap penurunan kandungan lemak tubuh (FM) dan peningkatan asam lemak bebas (FFA) pada perempuan overweight. Metode, 18 subjek penelitian menyelesaikan $4 \mathrm{x} /$ minggu latihan LICT atau MICT selama 5 minggu. LICT dan MICT dilakukan selama 30 menit dengan tambahan waktu 5 menit pemanasan dan 5 menit pendinginan dengan intensitas LICT 60\%-70\% dan MICT 70\%-80\% dari HR maksimal dimana kedua jenis latihan tersebut menggunakan ergocycle sedangkan pengukuran FM dan FFA diukur sebelum dan sesudah latihan. Hasil. Pada kelompok LICT terjadi signifakan pada lemak tubuh dan asam lemak bebas dengan tingkat signifikan $<0,05$ serta pada kelompok MICT juga mengalami signifikan pada lemak tubuh dan asam lemak bebas dengan tingkat signifikan $<0,05$. Pada perbandingan kedua kelompok antara LICT dan MICT secara deskriptif mengalami peningkatan akan tetapi hasil dari analisis tidak ada perbedaan antara kedua kelompok dengan nilai $\Delta \mathrm{FM}(\mathrm{p}=0.120)$ dan $\triangle \mathrm{FFA}$ $(\mathrm{p}=0.131)$ yang mana nilai tersebut $>0.05$. Kesimpulan. Latihan ini bisa digunakan sebagai penekanan terjadinya overweight di Indonesia dengan pengaturan jadwal latihan lagi.
\end{abstract}

Kata kunci-Lemak; Asam Lemak bebas; intensitas; Overweight

\begin{abstract}
This study aimed to determine the effect of Continuous Low Intensity Training (lict) and Moderate Intensity Continuous Training (MICT) to decrease body fat content (FM) and an increase in free fatty acids (FFA) in overweight women. Methods, 18 subjects completed the study $4 \mathrm{x} /$ week exercise LICT or MICT for 5 weeks. LICT and MICT performed for 30 minutes with an additional 5minute warm-up and 5 minutes of cooling with LICT intensity of $60 \%-70 \%$ and MICT $70 \%-80 \%$ of maximum HR where both types of exercise using ergocycle while FM measurement and FFA were measured before and after practice. Results. In the group significant LICT occur in body fat and free fatty acids with a significant level $<0,05$ and the MICT group also experienced significantly in body fat and free fatty acids with a significant level of $<0.05$. In the comparison between the two groups LICT and MICT in descriptive increased but the resulted of the analysis there was no difference between the two groups with $\Delta \mathrm{FM}$ value $(\mathrm{p}=0.120)$ and $\Delta \mathrm{FFA}(\mathrm{p}=0131)$ in which the value was $>$ 0.05 . Conclusion. This exercise can be used as an emphasis occurrence of overweight in Indonesia by setting exercise schedule again
\end{abstract}

Keywords-Fat; Free Fatty Acids; Intensity; Overweight 


\section{PENDAHULUAN}

Overweight merupakan ketidak seimbangan lemaak yang dapat mempengaruhi kesehatan yang mana merupakan salah satu masalah yang sekarang banyak dihadapi oleh negaranegara. Overweight dikatagorikan dengan $25-30 \mathrm{~kg} / \mathrm{m} 2$ dalam satuan indeks massa tubuh (Organization, 2018). Indonesia merupakan salah satu negara yang mengalami kenaikan jumlah overweight dari tahun $2007(8,8 \%)$ sampai $2013 \quad(13,5 \%)$ (Badan penelitian dan Pengembangan Kesehatan Kementerian Kesehatan, 2007; Kemenkes RI, 2013).

Angka overweight tersebut bisa ditekan dengan memberikan beberapa perlakuan, seperti halnya melakukan aktivitas olahraga yang dikategorikan dalam bentuk aerobik. Olahraga aerobik bisa melipolisis lemak/trigliserida yang mempengaruhi penggunaan lemaak tubuh dan asam lemak bebas menjadi energy dengan bantuan oksigen (Guyton and Hall, 2014). Hal tersebut terjadi dikarenakan trigliserida mengalami hidrolisis yang akan menghasilkan peleasan asam lemak dan dikirim ke jaringan aktif dimana akan di oksidasi (Wolinsky and Judy A Driskell, 2008).

Trigliserida tidak bisa langsung berubah menjadi asam lemak bebas dan gliseerol melainkan memerlukan bantuan dari beberapa hormon dan enzim. Hal tersebut bisa terstimulasi dikarenakan oleh aktivitas olahraga dengan durasi yang lama (Jeppesen and Kiens, 2012).hormon yang bekerja dalam membantu metabolisme lemak diantara lainnya yakni kortisol, katekolamin, hormon pertumbuhan, dll yang mana akan meningkatkan lipolisis trigliserida dengan menstimulasi $\beta$ androgenik reseptor dengan penambahan hormone sensitive lipase (HSL) akan tetapi untuk hormone perrtumbuhan bekerja ketika malam hari pada saat tubuh istirahat (Wolinsky and Judy A Driskell, 2008).

Okdisasi lemak akan terjadi ketika ketersediaan karbohidrat yang diproses dalam bentuk glikogen mulai habis. Lemak sendiri tidak bisa langsung digunakan sebagai energi dikarenakan rangkaian atau susunan kimianya sangat panjang dibanding dengan karbohidrat yang mencapai dua kali lipatnya, oleh sebab itu lemak akan disimpan didalam tubuh dalam bentuk trigliserida. Saat glukosa habis akan digantikan dengan trigliserida ini nanti akan di ubah kedalam bentuk asam lemak dan gliserol yang nantinya akan masuk kedalam siklus krebs dalam bentuk asam lemak.

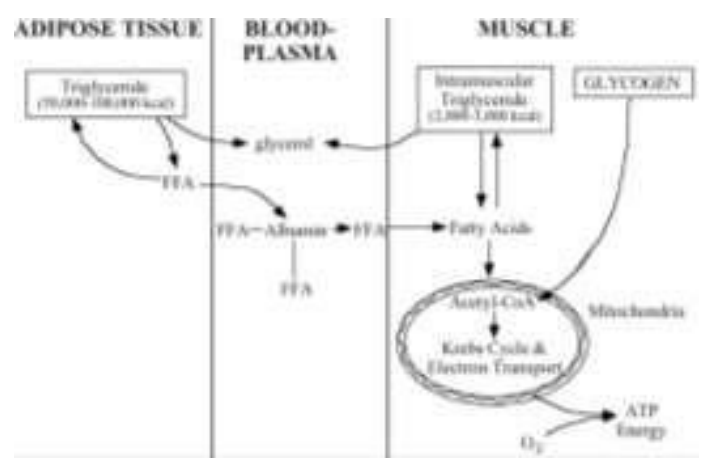

Gambar 1.1 Mekanisme jalur metabolisme lemak

Asam lemak sendiri bisa terproses jika memasuki mitokondria yang nantinya akan didegradasi dan dioksidasi. Langkah pertama penggunaan asam lemak yakni pengangkutan asam lemak ke dalam mitokondria yang menggunakan karnitin sebagai zat pembawa atau transport. Ketika masuk didalam mitokondria, asam lemak berpisah dengan karnitin dan didegradasi dan oksidasi (Guyton and Hall, 2014).

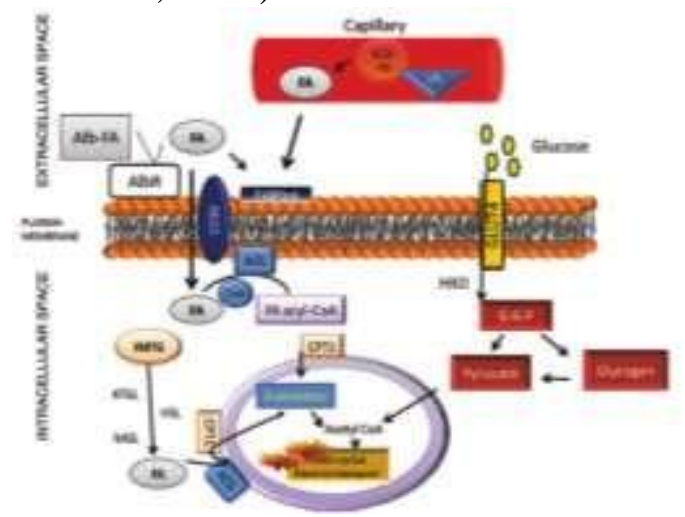

Gambar 1.2 Mekanisme Metabolisme lemak 
Metabolisme lemak tidak bisa terjadi dengan sendirinya. Ada bebrapa yang yang membantu dalam metabolisme lemak seperti halnya enzim dan hormon. Hormon ini sendiri keluar apabila mendapatkan suatu stimulus, salah satunya yakni karena suatu rangsangan dari latihan dengan durasi yang lama akan merangsang beberapa hormon untuk membantu metabolisme lemak (Jeppesen and Kiens, 2012). Respon lemak pada saat sesi latihan atau program latihan tergantung dari jenis latihan yang diambil termasuk intensitas dan frekuensi, durasi setiap latihan dan menghabiskan waktu seperti program latihan dengan latihan menggunakan sepeda ergometer dengan intensitas 50$70 \%$ dari heart rate maksimum (Kanna, 2014).

Metabolisme lemak tidak bisa terjadi dengan sendiri. Seperti yang diuraikan diatas bahwasannya peranan hormon juga penting dalam terjadinya liposis lemak. Hormon yang paling penting dalam metabolisme lemak yakni katekolamin (epinefrin dan norepinefrin) akan tetapi ketika latihan aerobik, hormone epinefrin akan meningkat. Hormon epinefrin digunakan untuk membantu menghidrolisis trigliserida. Tidak hanya hormon katekolamin yang bekerja saja, akan tetapi hormon kortisol dan hormone pertumbuhan juga berperan penting dalam peningkatan liposlisis katekolamin yang dirangsang dan juga mengatur lipolisis nocturnal (malam hari)"(Wolinsky and Judy A Driskell, 2008)

Pada saat latihan dengan intensitas rendah dan moderat, sekresi glukagon, cortisol, epeinefrin dan growth hormone merupakan secara dominan diatur oleh kebutuhan metabolisme dan sifat homeostasis dari orang tersebut. Pada saat latihan dengan intensitas rendah antara 25\% dan 50\% dari VO2max, saraf simpatik dan epinefrin mengalami dua kali lebih konsentrasi, akan tetapi selama latihan intensitas moderat antara 50\% dan $75 \%$ daro VO2max, plasma epinefrin dan norepinefrin meningkat konsentrasinya antara 4 sampai 6 kali. Pada saat intensitas tinggi di atas $75 \%$ dari VO2max, plasma epinefrin dan norepinefrin bisa mencapai 17 sampai 20 kali lebih tinggi dari pada saat istirahat. Pengaktifasian saraf simpatik selama latihan bertanggung jawab terhadap semua koordinasi dari kardirespiratori dan respon secara hormonal untuk stres, termasuk penekanan terhadap insulin dan menstimulasi glucagon, kortisol, dan sangat kemungkinan sekresi GH (Borer, 2013).

Umumnya latihan aerobik untuk orang obesitas atau berat badan lebih menurunkan massa tubuh, lemak tubuh, dan meningkatkan pendistribusian lemak tubuh yang menggunakan latihan saja atau mengkombinasikan dengan diet kalori juga menurunkan lemak tubuh dibandingkan dengan penurunan berat badan dengan metode diet (McArdle et al, 2010).

Latihan aerobik ada beberapa macam yakni latihan interval, latihan berkelanjutan (continuous), dan latihan fartlek. Para peneliti kebanyakan menggunakan latihan interval seperti halnya (Fisher et al., 2015; Kong et al., 2016; Wewege et al., 2017; H. Zhang et al., 2017) akan tetapi jarang yang menggunakan latihan berkelanjutan. Peneliti yang menggunakan latihan berkelanjutan yakni Keating dkk meneliti perbandingan dengan latihan interval dengan intensitas tinggi dibandingkan dengan latihan berkelanjutan dengan intensitas sedang dengan hasil siknifikan terhadap latihan berkelanjutan dengan intensitas sedang dari pada latihan interval dengan intensitas tinggi, (Keating et al., 2014).

Menurut Sahlin dalam Bompa (2015) tentang latihan aerobik yang berpengaruh terhadap lemak yakni latihan submaksimal dalam waktu jangka yang lama, seperti daya tahan dari latihan durasi yang lama atau sedang, glukosa dan lemak akan digunakan sebagai penyediaan energi yang juga membutuhkan oksigen. Ketika oksigen dalam batas ambang, glukosa akan dipecah dalam anaerob yang 
menghasilkan 2 ATP maka akan kekurangan energi sehingga akan mengoksidasi asam lemak bebas. Jumlah oksidasi lemak sendiri tergantung pada ketersediaan asam lemak bebas dalam otot dan tingkat aerobik atlet. Peningkatan latihan aerobik tergantung dari ketersediaan oksigen dan kapasitas oksidasi asam lemak (Bompa and Buzzichelli, 2015)

Untuk dapat mengetahui jumlah dari perhitungan denyut jantung sebagai tanda bahwa sudah masuk dalam zona latihan atau tidak dengan melakukan perhitungan denyut jantung maksimal. Sebuah alternatif dalam penghitungan HR yakni dengan menghitung HRmax seseorang. Perhitungan HRmax yakni: HRmax = 220 - Umur (tahun)

Perhitungan dengan perbedaan umur yakni memiliki rumus tersendiri yakni:

$$
\mathrm{THR}=[(\mathrm{MHR}-\mathrm{RHR}) \mathrm{x} \%]+\mathrm{RHR}
$$

Keterangan :

THR : Target Heart Rate

RHR : Restiing Heart Rate $(75 \mathrm{~b} / \mathrm{p})$

MHR : Maximum Heart Rate

$$
\text { (220 - umur) }
$$

Perhitungan diatas merupakan perhitungan yang paling mendakati perhitungan $\mathrm{VO}_{2}$ mak (de Moraes et al., 2016).

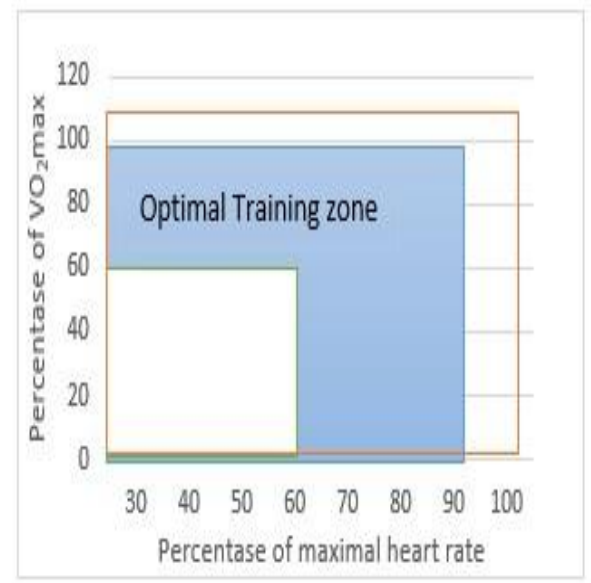

Peneliti lain yang menggunakan kapasitas dari VO2max, Gaesser dan Rich menggunakan VO2max dalam penelitiannya tentang lipid. Peneliti tersebut menggunakan intensitas rendah dan tinggi dengan perhitungan $85 \%-90 \%$ untuk intensitas tinggi dan $45 \%$ untuk latihan intensitas rendah dari kapasitas VO2max, (Glenn A, 2017), begitu juga dengan Siro dan Rohalla menggunakan perhitungan $70 \%$ dari Vo2max dengan durasi 30 menit (Hosseini and Valizadeh, 2012). Kong et al (2016b) meneliti tentang komposisi tubuh dan glukosa darah pada orang obesitas yakni menggunakan HIIT dan MICT dimana peneliti tersebut menghasilkan data lebih baik pada MICT meskipun untuk penghematan waktu lebih baik menggunakan HIIT dengan melakukan latihan sebanyak 4x/minggu selama 5 minggu (Kong et al., 2016b).

Penelitian tentang lemak sudah banyak dilakukan oleh para peneliti seperti halnya Fhiser et al (2015) yang menggunakan ergocycle untuk mengetahui komposisi tubuh, lemak pada darah, sensitif insulin, dan kebugaran kardiovaskular dengan menggunakan High Intensity Interval Training (HIIT) dan Continuous Moderate Intensity Training (MICT) menyatakan bahwa mengalami peningkatan dari hasil kedua latihan tersebut dan tentunya mengalami penurunan \%lemak tubuh (Fisher et al., 2015).

Penelitian lain yang meneliti tentang metabolisme lemak khususnya pada lemak abdominal visceral dan komposisi tubuh pada perempuan obesitas dengan gangguan metabolisme yang menngunakan latihan Low-Intensity Exercise Training (LIET) dan High-Intensity Exercise Training (HIET) diketahui hasilnya yakni data tersebut bahwa perubahan komposisi tubuh efektif dengan latihan intensitas HIET (Irving et al., 2009). Disisi lain dalam penelitian Lazer et al (2011) tentang komposisi tubuh dan susbtrat dari metabolisme pada laki-laki obesitas diketahui aktivitas fisik dengan intensitas rendah pada minggu ke 3 massa tubuh dan massa lemak menglami penurunan secara signifikan pada semua kelompok Low 
Intensity (LI) dan High Intensity (HI) dan penurunan paling signifikan yakni pada LI dibandingkan dengan HI (Lazzer et al., 2011)

Somatotip yakni tipe tubuh atau klasifikasi tubuh manusia. Klasifikasi dalam tubuh manusia dibagi menjadi 3 yakni endomorfi, mesomorfi, dan ektomorfi. Endomorfi yakni dalam Bahasa Indonesia dengan makna kegemukan dalam komponen tubuh. Komponen tubuh yang biasanya terjadi yakni pada perut yang melebihi torak dan leher yang pendek. Sedangakan untuk mesomorfi dikarakteristikan dengan tubuh kotak dengan keras, berat, dan otot menonjol. Tulang besar dan kedua kaki, batang, ddan kedua lengan berat pada seluruh otot. Karakteristik yang ketiga yakni ektomorfi, termasuk diklasifikan sebagai linearitas, rapuh, dan kehalusan tubuh. Karakter ini termasuk dalam karakteristik kurus. Tulang kecil dan otot sedikit (McArdle et al, 2010).
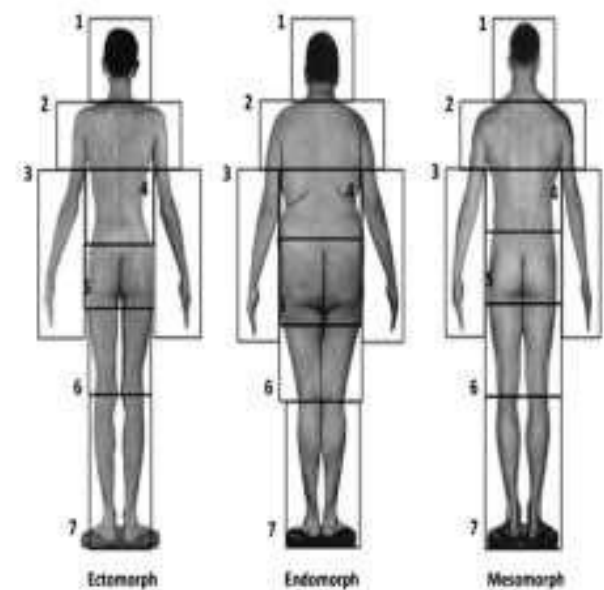

Gambar 1.3 Somatotip manusia

Menurut dalam jurnal Dixson et al (2010) yang mengambil dari peryataan peneliti lain yakni somatotip memberikan penilaian antropometri tiga dimensi seseorang yang mesomorfy (otot-otot), endmorfi (kegemukan), dan endomorfi (kerampingan/kurus). Pada pria mesomorfi memprediksi kekuatan yang lebih besar, daya tahan dan fungsi jantung. Endomorfi, ditandai dengan lemak tubuh lebih dan besar terhadap diabetes tipe II dan penyakit kardivaskular (Dixson et al., 2014)
Berat badan berlebih dan obesitas merupakan kebanyakan permasalahnan kesehatan masyarakat di banyak negara dunia. Hasil data yang didapatkan secara bertahap meningkat setiap tahunnya antara orang dewasa dan remaja serta pada orang tua lanjut. Hal ini menjadi perhatian khusus ketika orangberat badan berlebih pada tingkat ini bisa memicu bentuk obesitas pada orang dewasa (Frisancho, 2008). Sejalan dengan uraian diatas hal terssebut juga terjadi pada negara Indonesia. Menurut Riskesda (2010) menyajikan data tentang status gizi pada orang dewasa dengan hasil tamatan dari perguruan tinggi dengan jenis kelamin laki-laki mengalami berat badan berlebih dibandingkan dengan peremuan yakni 15,6 pada laki-laki dan pada perempuan 12,7 (Badan penelitian dan Pengembangan Kesehatan Kementerian Kesehatan, 2010).

Terdapat banyak macam dalam pengukuran tubuh. Beberapa teknik pengukuran yakni dengan menggunakan MRI, computed tomography, potassium40 counting, ultrasound imaging, total body electrical conductivity (TOBEC), isotop dilution, computer assistedaxial tomography, dan termography. Kebanyakan yang digunakan untuk mengukur komposisi tubuh yakni MRI dengan standart yang paling tinggi. Pada akhir-akhir ini banyak penelti juga menggunakan BIA (Bioelectrical impedance analysis) dan juga pengukuran menggunakan IMB (indeks masa tubuh) yang digunakan untuk mengetahui tingkat kesehatan seseorang. Pengukuran IMB yakni menggunakan rumus sebagai berikut:

$\mathrm{IMB}=$ berat tubuh $(\mathrm{kg}) /$ tinggi tubuh

$$
(\mathrm{m})^{2}
$$

Penelitian Yafuz yang meneliti tentang lemak tubuh menggunakan BIA sebagai pengukurannya (Yavuz, 2011). Peniliti Lin juga menggunakan BIA untuk mengukur komposisi tubuh tetapi pada orang sindrom Prader-Willi, (Lin et 
al., 2011). Peneliti Yeh dkk menggunakan BIA untuk mengetahui estimasi masa lemak bebas dari berbagi segmen pada orang Taiwan, (Yeh et al., 2012). Pada penelitian Zhang dkk meniliti komposisi tubuh dengan factor resiko metabolisme pada orang China menggunakan BIA, (L. Zhang et al., 2017). Pada penelitian Rebeyrol dkk menggunnakan BIA untuk memonitoring persiapan fisik pada penampilan atlet ski untuk kejuaran olimpik winter, (Rebeyrol et al., 2010). Hal yang serupa juga dilakukan oleh Scafoglieri dkk yang meniliti tentang prediksi apekdikular lean dan masa lemak pada orang tua dengan penurunan fungsi fisik, (Scafoglieri et al., 2017).

Iwayama dkk (2015) tentang oksidasi lemak yang menggunakan metode pengukuran sebelum makan pagi. Hasil yang didapat yakni adanya peningkatan oksidasi lemak sebelum makan pagi. Jurnal tersebut mengalami bias dalam penelitian, dikarenakan orang coba melakukan latihan dengan pilihannya mereka sendiri (Iwayama et al., 2015). Hasil dari beberapa peniliti kebanyakan menggunakan latihan interval akan tetapi penelitian tentang komposisi tubuh dan asam lemak bebas yang membandingkan antara Low Intensity Continuous Training (LICT) dan Moderate Intensity Continuous Training (MICT) belum pernah dilakukan.

\section{METODE PENELITIAN}

Peneilitian ini berjenis ekperimental pretest-posttest design. Subyek berjenis kelamin perempuan dengan rentang usia 1932 tahun sebanyak 18 orang. Latihan dibagi menjadi 2 kelompok antara LICT dan MICT. LICT menggunakan intensitas 60\%-70\% dari HR maksimal dengan durasi waktu latihan 30 menit serta penambahan waktu 5 menit untuk pemanasan 5 menit untuk pendinginan, dilakukan $4 x /$ minggu selama 5 minggu. Prosedur MICT hampir sama dengan LICT yang membedakan adalah intensitas 70\%-80\% dari HR maksimal. Selama latihan menggunakan ergocycle dan dipantau menggunakan polar heart rate monitor. Variable pada penitian ini adalah lemak tubuh dan asam lemak bebas. Lemak tubuh diukur menggunakan Bioimpandance Analyzer (BIA) dan asam lemak bebas diukur menggunakan Human Free Fatty Acid ELISA KIT. Analisis data menggunakan spss untuk mengatahui hasil dari pengolaharan data

\section{HASIL DAN PEMBAHASAN}

Tabel 3.1 Disitribusi frekuensi usia responden

\begin{tabular}{ccc}
$\begin{array}{c}\text { Kelompok } \\
\text { Usia }\end{array}$ & $\begin{array}{c}\text { responden } \\
\text { Frekuensi }\end{array}$ & Persen \\
\cline { 1 - 2 } $19-22$ & 11 & 61,1 \\
$23-24$ & 5 & 27,8 \\
$25-26$ & 1 & 5,6 \\
32 & 1 & 5,6 \\
\hline Total & 18 & 100,0 \\
\hline
\end{tabular}

Responden pada penelitian ini berjumlah 18 orang dengan rentang usia 1931 dengan jumlah yang mendominasi yakni pada usia kurang dari 22 tahun dengan jumlah 11 orang sampel. Distribusi usia responden dapat dilihat pada gambar dibawah ini:

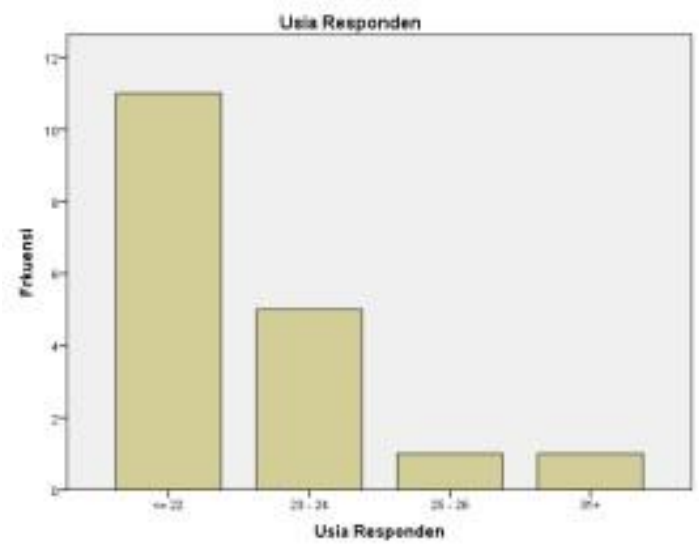

Gambar 3.1 Diagram batang distribusi usia responden

Tabel 3.2 Distribusi frekuensi indeks massa tubuh responden

\begin{tabular}{cccc}
\hline Kelompok & & & \\
IMT & Frekuensi & Persen \\
\cline { 3 - 3 } $25-27$ & & \\
$27,01-28,00$ & 6 & 27,8 \\
$28,01-29,00$ & 6 & 33,3 \\
$29,01-30,00$ & 1 & 33,3 \\
\hline Total & 18 & 100,6 \\
\hline
\end{tabular}


Pada tabel 3.2 diatas menunjukkan pada kelompok overweight dengan jumlah persentase yang paling banyak yakni pada kelompok 2 dan 3 dengan jumlah persentase mencapai $33,33 \%$. Interpretasi distibusi frekuensi IMT sampel penelitian dapat diketahui dari table dibawah ini:

Sampel pada penelitian ini memiliki rentang usia antara 19-32 tahun. Tabel 5.1 menunjukkan populisi pada penelitian ini didominasi pada usia kurang atau sama dengan dari 22 tahun dengan jumlah sebanyak 11 orang. Sampel penelitian ini menggunakan wanita dengan kategori overweight dengan angka tertinggi pada kelompok IMT yakni kelompok 27 sampai dengan $29 \mathrm{Kg} / \mathrm{m}^{2}$ sebanyak 6 orang masingmasing kelompok yang mana ditunjukkan pada tabel 3.2.

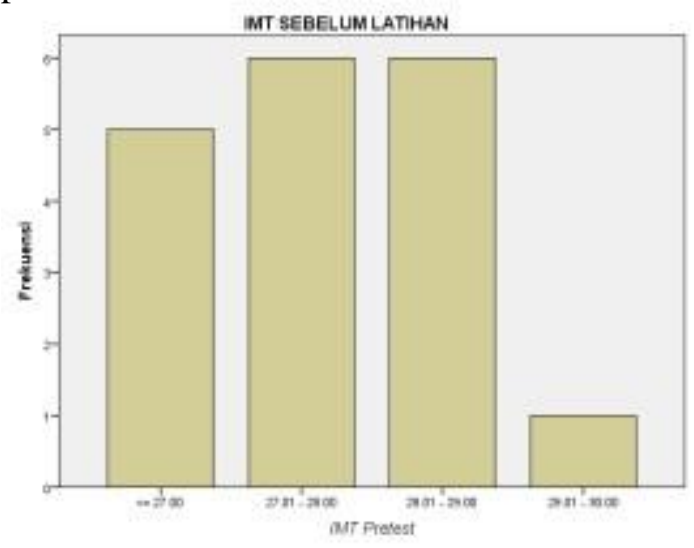

Gambar 3.2 Diagram batang IMT sebelum latihan

Tabel 3.5 Analisis deskriptif karakteristik sampel

\begin{tabular}{ccccc}
\hline & $\mathrm{n}$ & Minimun & Maksimum & Rer \\
\cline { 1 - 2 } $\begin{array}{c}\text { Usia } \\
\text { (tahun) }\end{array}$ & 18 & 19 & 32 & 22,39 \\
$\begin{array}{c}\text { IMT } \\
\text { Pretest }\end{array}$ & 18 & 26,03 & 29,52 & 27,65 \\
$\left(\mathrm{Kg} / \mathrm{M}^{2}\right)$ & & & & \\
\hline
\end{tabular}

3.1 Persentase lemak tubuh dan asam lemak bebas Hasil yang analisis uji normalitas

sebelum dan sesudah latihan Low dan Moddetatemenunjukkan nilai signifikansi pada Intensity

Tabel 3.6 Hasil analisis deskriptif

\begin{tabular}{|c|c|c|c|c|}
\hline & $\mathrm{n}$ & Min & Maks & Rerata \pm Simal. Hasil uji normalitas data delta lemak \\
\hline $\begin{array}{l}\text { Pre Lemak } \\
\text { Tubuh }\end{array}$ & 18 & 31.10 & 48.89 & $\begin{array}{c}\text { tubuh }(\mathrm{p}=0,0617) \text { dan asam lemak bebas } \\
39.8483 \pm(40,2828) 1 \\
\text { menunjukkan nilai signifaknasi lebih }\end{array}$ \\
\hline
\end{tabular}

\begin{tabular}{|c|c|c|c|c|}
\hline $\begin{array}{l}\text { Post } \\
\text { Lemak } \\
\text { Tubuh }\end{array}$ & 18 & 30.00 & 47.89 & $38.3361 \pm 4.91210$ \\
\hline Pre Asam & & & & \\
\hline $\begin{array}{l}\text { Lemak } \\
\text { Bebas }\end{array}$ & 18 & 710.057 & 897.133 & 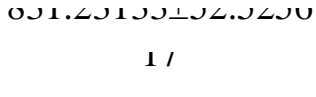 \\
\hline $\begin{array}{c}\text { Post Asam } \\
\text { Lemak } \\
\text { Bebas }\end{array}$ & 18 & 801.473 & 994.551 & 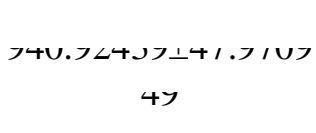 \\
\hline
\end{tabular}

Tabel 3.7 Hasil uji normalitas data dengan Shapi-Wilk

\begin{tabular}{|c|c|c|}
\hline \multirow{2}{*}{\multicolumn{2}{|c|}{ Kelompok }} & $\begin{array}{c}\text { Shapiro- } \\
\text { Wilk }\end{array}$ \\
\hline & & Sig. \\
\hline Pre & Low Intensity & 0,062 \\
\hline $\begin{array}{l}\text { Lemak } \\
\text { Tubuh }\end{array}$ & $\begin{array}{l}\text { Moderate } \\
\text { Intensity }\end{array}$ & 0,451 \\
\hline Post & Low Intensity & 0,134 \\
\hline $\begin{array}{l}\text { Lemak } \\
\text { Tubuh }\end{array}$ & $\begin{array}{l}\text { Moderate } \\
\text { Intensity }\end{array}$ & 0,337 \\
\hline Pre & Low Intensity & 0,998 \\
\hline $\begin{array}{c}\text { Asam } \\
\text { Lemak } \\
\text { Bebas }\end{array}$ & $\begin{array}{l}\text { Moderate } \\
\text { Intensity }\end{array}$ & 0,076 \\
\hline Post & Low Intensity & 0,174 \\
\hline $\begin{array}{c}\text { Asam } \\
\text { Lemak } \\
\text { Bebas }\end{array}$ & $\begin{array}{l}\text { Moderate } \\
\text { Intensity }\end{array}$ & 0,185 \\
\hline
\end{tabular}
normalitas data pada penelitian ini. Hasil dari penelitian ini menunjukkan signifikan dengan nilai $>0,05$ yang mana nilai tersebut menunjukkan bahwasannya data dari penelitian ini berdistribusi normal. Pada penelitian ini diawali dengan Rerata_8qDgunakan analisis deskriptif yang mana

untuk mengetahui sebaran persentase lemak $22,39 \pm 2,9953$ dan acam lemak hehas cehelım dan sesudah latihan low dan moderate intensity.

$27,65 \pm 0$ Rergta besaran lemak tubuh dan asam lemak bebas sebelum dan sesudah latihan low dan moderate intensity dapat dilihat pada tabel 3.7 . kelompok low dan moderate intensity lebih besar dari 0,05 , sehingga data berdistribusi Tubuh 
besar dari 0,05 dengan hasil data berdistribusi normal.

3.1.1 Hasil uji data penurunan lemak tubuh dan peningkatan asam lemak bebas pada latihan Low Intensity

Tabel 3.3 Hasil analisis data penurunan lemak tubuh dan peningkatan asam lemak pada latihan Low Intensity menggunakan pair t test

\begin{tabular}{|c|c|c|}
\hline Variabel & Rerata \pm SD & Sig. \\
\hline $\begin{array}{lr}\text { Pretest } & \text { Lemak } \\
\text { Tubuh } & - \\
\text { Posttest } & \text { Lemak } \\
\text { Tubuh } & \end{array}$ & $1,863 \pm 1,193$ & 0,002 \\
\hline $\begin{array}{l}\text { Pretest Asam } \\
\text { Lemak Bebas - } \\
\text { Posttest Asam } \\
\text { Lemak Bebas }\end{array}$ & $-126,102 \pm 47,054$ & 0,000 \\
\hline
\end{tabular}

Tabel 3.3 menunjukkan hasil uji data tentang pengaruh latihan terhadap penurunan lemak tubuh dan peningkatan asam lemak bebas yang menujukkan dari kedua latihan tersebut terdapat perbedaan antara sebelum dan sesudah pemberian latihan yang mana hasil uji analisis menunjukkan nilai signifikasi $<0,05$ antara pre lemak tubuh - post lemak tubuh $(\mathrm{p}=0,002)$ dan pre asam lemak bebas - post asam lemak bebas $(\mathrm{p}=0,000)$.

Pada uji data penurunan lemak tubuh dan peningkatan asam lemak bebas pada latihan low intensity menggunakan pair $t$ test. Uji tersebut digunakan dengan tujuan untuk melihat hasil perubahan dari lemak tubuh dan asam lemak bebas yang menggunakan latihan low intensity. Hasil uji analisis tersebut menunjukkan terjadi penurunan lemak tubuh $(\mathrm{p}=0,002)$ dan peningkatan asam lemak bebas $(\mathrm{p}=0,000)$ secara signifikan dengan nilai (p) kurang dari 0,05

Peneilitian ini mendukung teori yang dikemukan oleh Wolinsky dan Driskell (2018) yang menyatakan karbohidrat dan lemak merupakan penyedia utama dari energi selama latihan daya tahan. Lemak merupakan penyedia utama energi selama istirahat dan selama aktivitas dan latihan low intensity.
Hal ini terjadi karena meningkatnya asam lemak bebas yang diakibatkan dari latihannya dan mestimulasi hormon kortisol, katekolamin, dan hormon pertumban meningkat serta menstimulasi $\beta$ androgenik reseptor meningkat yang mengakibatkan meningkatnya lipolisis trigliserida melalui bantuan HSL(Hornon sensitif lipase) (Wolinsky and Judy A. Driskell, 2008). Penelitian ini mendukung teori dari Purdom et al (2018) yang menyatakan ketika latihan kurang dari $60 \%$ akan menstimulasi endorin untuk melepaskan epinefrin yang mana akan meningkatkan lipolisis dan konsentrasi epinefrin akan meningkat sebanyak 2-3 kali ketika istirahat (Purdom et al., 2018), dan menstimulasi HSL untuk diproduksi lebih banyak lagi guna melipolisis TG menjadi FFA dan gliserol (You et al., 2012). Lazer et al (2011) sejalan juga dengan teori diatas yang mengungkapkan Low intensity mendukung terjadinya okasidasi lemak dan disarakan untuk orang yang overweight atau obesitas yang mana lebih layak dan dapat diterima (Lazzer, Lafortuna and Italiano, 2011). Peneliti lain juga menggungkapkan yang sama yakni latihan aerobik mempunyai efek pada lemak tubuh, darah, dan kebugaran pada overweight dan obesistas (Powell, 2011)

\subsubsection{Hasil uji data penurunan lemak tubuh dan peningkatan asam lemak bebas pada latihan Moderate Intensity}

Tabel 3.4 Hasil analisis data penurunan lemak tubuh dan peningkatan asam lemak pada latihan Moderate Intensity menggunakan pair t test

\begin{tabular}{lcc}
\hline \multicolumn{1}{c}{ Variabel } & Rerata \pm SD & Sig. \\
\hline $\begin{array}{l}\text { Pretest Lemak } \\
\text { Tubuh - Posttest } \\
\text { Lemak Tubuh }\end{array}$ & $1,161 \pm 0,473$ & 0,000 \\
\hline $\begin{array}{l}\text { Pretest Asam } \\
\text { Lemak Bebas - } \\
\text { Posttest Asam } \\
\text { Lemak Bebas }\end{array}$ & $93,283 \pm 40,025$ & 0,000 \\
\hline
\end{tabular}

Tabel 3.4 menunjukkan hasil uji data tentang pengaruh latihan terhadap penurunan lemak tubuh dan peningkatan asam lemak bebas yang menujukkan dari kedua latihan tersebut terdapat perbedaan 
antara sebelum dan sesudah pemberian latihan yang mana hasil uji analisis menunjukkan nilai signifikasi $<0,05$ antara pre lemak tubuh - post lemak tubuh $(\mathrm{p}=0,000)$ dan pre asam lemak bebas - post asam lemak bebas $(\mathrm{p}=0,000)$.

Pada uji data penurunan lemak tubuh dan peningkatan asam lemak bebas pada latihan moderate intensity menggunakan pair $t$ test. Uji tersebut digunakan dengan tujuan untuk melihat hasil perubahan dari lemak tubuh dan asam lemak bebas yang menggunakan latihan moderate intensity. Hasil uji analisis tersebut menunjukkan terjadi penurunan lemak tubuh $(\mathrm{p}=0,000)$ dan peningkatan asam lemak bebas $(\mathrm{p}=0,000)$ secara signifikan dengan nilai (p) kurang dari 0,05

Sejalan dengan peryataan dari Ogasawara et al (2015) yang menyatakan latihan moderate intensity akan menyebabkan percepatan respon dari lipolisis pada manusia. Selama latihan moderate intensity kelompok asam lemak bebas berikatan dengan karnitin yang akan membawa keluar dari membrane mitokondria dalam bentuk acyl-karnitin. Ini terjadi pada latihan low ke moderate intensity (Ogasawara et al., 2015).

Hasil diatas sejalan dengan temuan Wewege et al (2017) yang mengungkapkan perubahan pada lemak tubuh dan lingkar pinggang mengalami perubahan ketika latihan MICT.(Wewege et al., 2017). Sejalan dengan Horowitz dan Klein (2000) latihan aerobik juga meningkatkan oksidasi lemak selama latihan submaksimal yang mana hasil dari respon adaptasi tubuh untuk meningkatkan ketebalan mitokindria pada otot tulang dan juga meningkatkan kapasitas oksidasi lemak. Latihan aerobik dengan durasi 30 menit akan mengalami peningkatan terhadap lipoisis lemak. menunjukkan bahwasannya pada menit ke 30 terjadi peningkatan lipolisis lemak yang mana juga dimbangi dengan meningkatnya penggunaan asam lemak. (Horowitz and Klein, 2000).

3.1.3 Hasil uji data perbandingan antara latihan Low dan Moderate Intensity terhadap penurunan lemak tubuh dan peningkatan asam lemak bebas

Tabel 3.8 Hasil analisis perbandingan antara latihan Low Intensity dan Moderate Intensity terhadap penurunan lemak tubuh dan peningkatan asam lemak bebas menggunakan independent t test

\begin{tabular}{|c|c|c|c|}
\hline \multicolumn{2}{|c|}{ Kelompok } & Rerata \pm SD & Sig. \\
\hline \multirow{2}{*}{$\begin{array}{c}\Delta \\
\mathrm{LT}\end{array}$} & $\begin{array}{c}\text { Low } \\
\text { Intensity }\end{array}$ & $-1,863 \pm 1.193$ & \multirow{2}{*}{0,120} \\
\hline & $\begin{array}{l}\text { Moderate } \\
\text { Intensity }\end{array}$ & $-1,161 \pm 0,473$ & \\
\hline \multirow{2}{*}{$\begin{array}{c}\Delta \\
\mathrm{ALB}\end{array}$} & $\begin{array}{c}\text { Low } \\
\text { Intensity }\end{array}$ & $123,102 \pm 27,054$ & \multirow{2}{*}{0,131} \\
\hline & $\begin{array}{c}\text { Moderate } \\
\text { Intensity }\end{array}$ & $93,283 \pm 40,025$ & \\
\hline
\end{tabular}

Ket: LT: Lemak Tubuh, ALB: Asam Lemak Bebas

Tabel 3.8 menunjukkan kadar lemak tubuh dan asam lemak bebas pretest dan posttest dengan latihan Low dan Moderate Intensity. Hasil posttest pada kedua variabel menunjukan adanya pengaruh dari latihan Low maupun Moderate Intensity dengan hasil interpretasi secara signifikan pada lemak tubuh $(\mathrm{p}=0.000)$ dan asam lemak bebas $(p=0,010)$. Hasil uji independent $t$ untuk mengetahui latihan yang efektif antara latihan Low dan Moderate Intensity tidak menunjukkan hasil perbedaan signifikan antara lemak tubuh $(\mathrm{p}=0,120)$ dan asam lemak bebas $(\mathrm{p}=0,131)$ dengan nilai signifikansinya $>0,05$, meskipun secara deskriptif dari kedua latihan tersebut menunjukkan adanya peningkatan lemak tubuh dan penurunan asam lemak bebas. Hasil tersebut bisa dilihat dari tabel 3.8 di atas.

Uji perbandingan anatara latihan low dan moderate intensity terhadap penurunan lemak tubuh dan peingkatan asam lemak bebas menggunakan analisis independent $t$ test. Uji analisis tersebut di maksudkan untuk mengatahui kedua latihan tersebut yang lebih berpengaruh terhadap penurunan lemak tubuh dan peningkatan asam lemak bebas yang lebih efektif. Hasil analisis independent $t$ 
test menunjukkan hasil antara delta lemak tubuh $(\mathrm{p}=0.120)$ dan delta asam lemak bebas $\quad(p=0.131) \quad$ tidak menunjukkan signifikan dengan nilai $(\mathrm{p})$ lebih besar dari 0,05

Hal ini juga sejalan dengan penelitian Kong et al (2016) yang mana membandingkan latihan HIIT dan MICT dengan hasil tidak adanya perubahan pada komposisi tubuh akan tetapi dilihat dari penngunaannya lebih tinggi MICT dari HIIT (Kong et al., 2016b). Pada penelitian Lazer et al (2011) membandingkan latihan LI dan HI tidak adanya perbedaan signifikan pada lemak antara kelompok LI dan HI (Lazzer, Lafortuna and Italiano, 2011). Pada penelitian Marra et al (2005) juga mendapati hasil yang sama yakni tidak adanya perbedaan signifikan pada lemak tubuh dari kelompok moderate intensity (Marra et al., 2005). Secara deskriptif terdapat perbedaan antara latihan LICT dan MICT yang mana nilainya lebih besar pada LICT. Temuan tersebut sesusai dengan teori Wolinsky et al (2008) yang menggunakapkan terjadi penurunan lemak paling banyak terjadi pada low intensity yang diakibatkan meningkatnya lipolisis pada jaringan adipose trigliserida (Wolinsky and Judy A Driskell, 2008).

Hal ini menandakan bahwa latihan aerobik menandakan bahwasannya bisa mengurangi jumlah lemak tubuh dan meningkatkan asam lemak bebas yang mana didapati hasil LICT dan MICT menunjukkan adanya perubahan setelah latihan. Hasil penelitian bisa menjadi pertimbangan dalam penekanan jumlah angka overweight dengan latihan LICT dan MICT menggunakan ergocycle, sehingga penerapan latihan pada LICT dan MICT membutuhkan pengaturan jadwal latihan

\section{KESIMPULAN DAN SARAN}

Pada penilitian ini terjadi penurunan lemak tubuh dan peningkatan asam lemak bebas pada LICT dan MICT, akan tetapi hasil perbandingan uji analisis statistik spss pada LICT dan MICT terjadi kecenderungan penurunan lemak tubuh dan peningkatan asam lemak bebas. Rekomendasi. Perlu adanya pengaturan jadwal latihan di kemudian pada peneliti lain yang akan meneliti hal serupa dengan ini

\section{UCAPAN TERIMA KASIH}

Terimakasih atas semua bantuan yang diberikan baik secara moril dan materi terhadap orang tua penulis dan pembimbing

\section{DAFTAR PUSTAKA}

Badan penelitian dan Pengembangan Kesehatan Kementerian Kesehatan (2007) 'Riset Kesehatan Dasar'. doi: 1 Desember 2013.

Badan penelitian dan Pengembangan Kesehatan Kementerian Kesehatan (2010) 'Riset Kesehatan Dasar'. doi: 1 Desember 2013.

Bompa, T. and Buzzichelli, C. (2015) Periodization Training for Sports-3rd Edition. Available at: https://books.google.com/books?id=Z b7GoAEACAAJ\&pgis $=1$.

Borer, K. T. (2013) Advanced Exercise Endocrinology, Journal of Sports Sciences. doi: 10.1080/02640414.2013.826930.

Dixson, B. J. et al. (2014) 'Eye-tracking women's preferences for men's somatotypes', Evolution and Human Behavior. Elsevier Inc., 35(2), pp. 7379. doi:

10.1016/j.evolhumbehav.2013.10.003

Fisher, G. et al. (2015) 'High intensity interval- vs moderate intensitytraining for improving cardiometabolic health in overweight or obese males: A Randomized controlled trial', PLOS ONE, 10(10), pp. 1-15. doi:

10.1371/journal.pone.0138853.

Frisancho, A. R. (2008) Anthropometric indexes of overweight and obesity as predictors of lipid changes in adolescents, University of Michigan

Press. doi: http://dx.doi.org/10.1590/S010305822011000100007.

Glenn A, G. (2017) 'Effects of high- and 
low-intensity exercise training on aerobic capacity and blood lipids', Medicine \& Science in Sports \& Exercise, (July 1984). doi: 10.1249/00005768-19840600000012.

Horowitz, J. F. and Klein, S. (2000) 'Lipid metabolism during endurance exercise 1-3', Am J Clin Nutr, 72(2), pp. 558-563. doi:

10.1093/ajcn/72.2.558S.

Hosseini, S. and Valizadeh, R. (2012)

'The effects aerobic exercise on some pulmonary indexes, body composition, body fat distribution and VO2max in normal and fat men of personal and members of faculty of Azad university Bebahan branch', Procedia Social and Behavioral Sciences, 46, pp. 3041-3045. doi: 10.1016/j.sbspro.2012.06.006.

Irving, B. A. et al. (2009) 'Effect of exercise training intensity on abdominal visceral fat and body composition', Med Sci Sports Exerc, 40(11), pp. 1863-1872. doi: 10.1249/MSS.0b013e3181801d40.Eff ect.

Iwayama, K. et al. (2015) 'Exercise Increases 24-h Fat Oxidation Only When It Is Performed Before Breakfast', EBioMedicine. The Authors, 2(12), pp. 2003-2009. doi: 10.1016/j.ebiom.2015.10.029.

Jeppesen, J. and Kiens, B. (2012) 'Regulation and limitations to fatty acid oxidation during exercise', The Journal of Physiology, 590(5), pp. 1059-1068. doi: 10.1113/jphysiol.2011.225011.

Kanna, D. U. (2014) 'Effect of Exercise Intensity on Lipid Profile in Sedentary Obese Adults', Journal of Clinical and Diagnostic Research, 8(7), pp. 8-10. doi: 10.7860/JCDR/2014/8519.4611.

Keating, S. E. et al. (2014) 'Continuous Exercise but Not High Intensity Interval Training Improves Fat
Distribution in Overweight Adults', Journal of Obesity, 2014, pp. 25-27. doi: 10.1155/2014/834865.

Kemenkes RI (2013) 'Riset Kesehatan Dasar 2013', Ministry of Health Republic of Indonesia, (1), pp. 1-303. doi: 10.1007/s13398-014-0173-7.2.

Kong, Z. et al. (2016a) 'Short-Term High-Intensity Interval Training on Body Composition and Blood Glucose in Overweight and Obese Young Women', Journal of Diabetese Research, 2016, pp. 10-12.

Kong, Z. et al. (2016b) 'Short-Term High-Intensity Interval Training on Body Composition and Blood Glucose in Overweight and Obese Young Women', Journal of Diabetes Research. Hindawi Publishing Corporation, 2016, pp. 10-12. doi: 10.1155/2016/4073618.

Lazzer, S. et al. (2011) 'Effects of lowand high-intensity exercise training on body composition and substrate metabolism in obese adolescents', Journal of Endocrinological Investigation, 34(1), pp. 45-52. doi: $10.3275 / 7238$.

Lazzer, S., Lafortuna, C. L. and Italiano, I. R. C. C. S. I. A. (2011) 'Effects of low- and high-intensity exercise training on body composition and substrate metabolism in obese adolescents', Journal of endocrinological investigation, (April 2014). doi: 10.3275/7238.

Lin, H. Y. et al. (2011) 'Assessment of body composition using bioelectrical impedance analysis in Prader-Willi syndrome', Journal of the Formosan Medical Association. Elsevier Taiwan LLC, 110(11), pp. 719-723. doi: 10.1016/j.jfma.2011.09.010.

Marra, C. et al. (2005) 'Effect of Moderate and High Intensity Aerobic Exercise on the Body Composition of Overweight Men', Journal of Exercise Physiology Online, 8(2), pp. 39-45. Available at: 
http://articles.sirc.ca/search.cfm?id=S

1033854\%5Cnhttp://ezproxy.lib.ucon n.edu/login?url=http://search.ebscoho st.com/login.aspx?direct $=$ true $\& \mathrm{db}=\mathrm{sp}$ h\&AN=SPHS-1033854\&site=ehostlive \&scope $=$ site $\% 5 \mathrm{Cnhttp}: / / \mathrm{www}$.ase p.org/.

de Moraes, R. et al. (2016) 'Effects of non-supervised low intensity aerobic excise training on the microvascular endothelial function of patients with type 1 diabetes: A nonpharmacological interventional study', BMC Cardiovascular Disorders. BMC Cardiovascular Disorders, 16(1), pp. 1-9. doi: 10.1186/s12872-016-0191-9.

Ogasawara, J. et al. (2015) 'The molecular mechanism underlying continuous exercise training-induced adaptive changes of lipolysis in white adipose cells', Journal of Obesity, 2015. doi: 10.1155/2015/473430.

Organization, W. H. (2018) Overweight and Obesity. doi: 10.1016/j.spinee.2013.09.052.

Powell, M. (2011) Physical Fitness: Training, Effects and Maintaining.

Purdom, T. et al. (2018) 'Understanding the factors that effect maximal fat oxidation', Journal of the

International Society of Sports Nutrition. Journal of the International Society of Sports Nutrition, 15(1), pp. 1-10. doi: 10.1186/s12970-018-02071.

Rebeyrol, J. et al. (2010) 'Bioimpedance data monitoring in physical preparation: A real interest for performance of elite skiers for Winter Olympic Games 2010', in Procedia Engineering, pp. 2881-2887. doi: 10.1016/j.proeng.2010.04.082.

Scafoglieri, A. et al. (2017) 'Predicting appendicular lean and fat mass with bioelectrical impedance analysis in older adults with physical function decline - The PROVIDE study', Clinical Nutrition. Elsevier Ltd,
36(3), pp. 869-875. doi: 10.1016/j.clnu.2016.04.026.

Wewege, M. et al. (2017) 'The effects of high-intensity interval training vs. moderate-intensity continuous training on body composition in overweight and obese adults: a systematic review and meta-analysis', Obesity Reviews, pp. 635-646. doi: 10.1111/obr.12532.

Wolinsky, I. and Driskell, J. A. (2008) Sports nutrition : energy metabolism and exercise.

Wolinsky, I. and Driskell, J. A. (2008) Sports Nutrtion.

Yavuz, S. C. (2011) 'Effect of maximal exercise on percent body fat using bioelectrical impedance analysis in active males', International Journal of Human Sciences, 8(1), pp. 820 828. Available at:

http://search.ebscohost.com/login.asp $\mathrm{x}$ ?direct $=$ true $\& \mathrm{db}=\mathrm{a} 9 \mathrm{~h} \& \mathrm{AN}=776941$ 20\&site $=$ ehost-live.

Yeh, C. et al. (2012) 'Bioelectrical impedance analysis in a mathematical model for estimating fat-free mass in multiple segments in elderly Taiwanese males', International Journal of Gerontology. Elsevier Taiwan LLC., 6(4), pp. 273-277. doi: 10.1016/j.ijge.2012.01.031.

You, T. et al. (2012) 'Effect of exercise training intensity on adipose tissue hormone sensitive lipase gene expression in obese women under weight loss', Journal of Sport and Health Science. Elsevier Ltd, 1(3), pp. 184-190. doi: 10.1016/j.jshs.2012.10.001.

Zhang, H. et al. (2017) 'Comparable Effects of High-Intensity Interval Training and Prolonged Continuous Exercise Training on Abdominal Visceral Fat Reduction in Obese Young Women', Journal of Diabetes Research. Hindawi Publishing Corporation, 2017. doi: 10.1155/2017/5071740.

Zhang, L. et al. (2017) 'Association of 
Jurnal Biosains Pascasarjana Vol. 20 (2018) pp (C) 2018 Sekolah Pascasarjana Universitas Airlangga,

body composition assessed by

bioelectrical impedance analysis with metabolic risk factor clustering among middle-aged Chinese', Preventive Medicine Reports. The Authors, 6, pp. 191-196. doi: 10.1016/j.pmedr.2017.03.011. 